\title{
Incorporation of Multi-Strain Probiotic Preparation in a Traditional Brazilian Cheese: Effects on Microbiological Safety and Bacterial Community
}

\author{
Moysés Estevão de S. F. Pehrson ${ }^{1}$, Viviane Lívia C. Souza ${ }^{1} \&$ Ismael M. Mancilha ${ }^{1}$ \\ ${ }^{1}$ Escola de Engenharia de Lorena, University of São Paulo, Lorena, SP, Brazil \\ Correspondence: Moysés Estevão S. F. Pehrson, Escola de Engenharia de Lorena, Department of industrial \\ biotechnology, Universidade de São Paulo São Paulo, Lorena, CEP 12600-970, Brazil. Tel: 55-249-8824-6079. \\ E-mail: moyses.freitas@gmail.com
}

Received: September 3, 2019

Accepted: October 29, 2019 Online Published: November 6, 2019

doi:10.5539/jfr.v9n1p1

URL: https://doi.org/10.5539/jfr.v9n1p1

\begin{abstract}
Consumer preference for raw milk cheeses has increased in the past few years. This occurred partly due to their more diverse, enjoyable characteristics, but also due to claims that certain members of the autochthonous microbiota of milk can be beneficial to human health. These microorganisms can inhibit the growth of undesirable microorganisms and may also be used to establish a biogeographic identity for these products. The aim of this study was to assess the effect of a multi-strain probiotic preparation on the microbiological safety and composition of bacterial community of a traditional Brazilian raw milk cheese by means of culture dependent and methods and pyrosequencing. Probiotic enriched cheeses presented an average of 50\% less sequence reads belonging to Enterobacteriaceae than control cheeses. Total and thermotolerant coliforms cell viability decreased throughout ripening in two seasons (summer and autumn), while in the winter the presence of these microorganisms was negligible since the beginning of ripening. Results obtained through culture dependent method did not correlate with culture independent method, which pointed to a relatively constant number of Enterobacteriaceae reads during ripening. Viable cells of coagulase positive Staphylococcus aureus stayed within legal limits in both groups of cheeses since the first day and decreased to zero at the $15^{\text {th }}$ day in probiotic enriched cheeses. Salmonella sp. and Listeria sp. were absent in both control and probiotic groups. Our results support that enriching raw milk cheeses with probiotic bacteria or other bioprotective bacteria may help mitigate off flavors produced by Enterobacteriaceae and result in safer products by inhibiting the growth of these microorganisms, while maintaining the microbial diversity that may be beneficial to sensory profiles and health-promoting characteristics. We also showed that this traditional cheese, if made under right the conditions, can meet legal parameters in much less than 60 days of ripening.
\end{abstract}

Keywords: artisanal cheese, microbiota, probiotics, raw milk cheese

\section{Introduction}

Global cheese market is expected to reach $\$ 164,338$ million dollars in 2023. In 2016, North America and Europe occupied nearly $80 \%$ of this market, with cheeses like mozzarella and cheddar dominating the exportation market (www.alliedmarketresearch.com). Brazil is a minor player in the global market of cheeses, however, the recent slow food movements contributed in increasing both the consumption and the production of traditional products such as artisanal cheeses and other naturally fermented and minimally processed foods.

Raw milk cheeses are becoming preferred over pasteurized milk cheeses by an increasing percentage of consumers for having stronger and/or more pleasant sensory characteristics. These characteristics have been linked to various members of milk's autochthonous microbiota, like Lactococcus spp., Lactobacillus spp., Leuconostoc spp and Enterococcus spp (Casalta, Sorba, Aigle, \& Ogier, 2009; Masoud et al., 2012). These fermented products can harbor a large variety of bacteria which are capable of inhibiting both spoilage as well as pathogenic microorganisms, thus extending shelf-life and increasing safety of these products (O'Sullivan \& Cotter, 2017). Additionally, raw milk cheeses present a big potential as reservoirs of health-promoting bacteria known as probiotics. This can be verified by the abundance studies like the ones from Elkenany, Mona, Eltaysh, Zakaria \& El-Baz (2018), Eid et al. (2016) and Valente et al. (2019) which evaluated probiotic characteristics in 
microorganisms originally isolated from raw milk or raw milk cheeses.

According to the slight redefinition of the term by Hill et al. (2014), probiotics are "live microorganisms that, when administered in adequate amounts, confer a health benefit on the host". One of the benefits offered by probiotics is the protection against colonization by potentially pathogenic bacteria and in some cases, active inhibition of already established detrimental intestinal bacteria. This inhibition can be attributed to the production of antimicrobial substances, in special organic acids, bacteriocins and other inhibitory metabolites, which can be applied to other fields such as food quality and safety. The main representatives of probiotic bacteria belong to a phylogenetically diverse group known as Lactic Acid Bacteria (LAB).

Lactic acid bacteria are naturally occurring in raw milk and are capable of inhibiting a wide range of bacterial contaminants, such as Salmonella sp. Staphylococcus aureus, Listeria monocytogenes and members of the Enterobacteriaceae family. During the processing and ripening of raw milk cheeses LAB produce organic acids and other antimicrobial compounds, which inhibit the growth of undesirable microorganisms, acting as bioprotectants and rendering these products safer for consumption after a period of time that depends on ripening conditions, type and abundance of beneficial LAB. However, microbial composition may vary greatly between different batches of cheese, therefore a consistent percentage of bioprotective microorganisms must be ensured in order to guarantee the safety of raw milk cheeses (Yoon, Lee, \& Choi, 2016).

According to Chambers, Esteve \& Retiveau (2010), pasteurization directly interferes in sensory profiles of ripened cheeses by stripping them of their regional and seasonal characteristics. This effect can be attributed to the elimination of milk's autochthonous microbiota during pasteurization, which would then alter the proportion of fermentation end products during ripening, thus altering flavor and aroma profiles. However, food safety is also linked to microbial composition of raw milk and there are inherent risks of utilizing raw milk for cheese making (Law \& Tamime, 2010; Quigley et al., 2013). In this context, elimination of autochthonous microbiota can also strip these products of most of their microbiota-associated benefits like the presence of probiotic lactic acid bacteria and microbial digestive enzymes.

Moreover, studying the composition of microbial communities in fermented foods can help to establish a link between microbial diversity or specific community compositions to their practical consequences, such as desirable/undesirable flavor profiles, increased protection against spoilage and pathogenic bacteria and in establishing a product identity (Dutton \& Wolfe, 2015).

Our hypothesis was that enriching the milk's autochthonous microbiota with probiotic microorganisms prior to cheese making would result in safer products through the inhibition of potentially dangerous microorganisms, reducing the ripening time required for raw milk cheeses to be considered safe for consumption.

In order to test this hypothesis, a traditional Brazilian raw milk cheese, known as "Queijo da Mantiqueira" was studied in three different seasons, with and without the addition of probiotics. Effects of probiotics on microbiological quality indicators such as total and thermotolerant coliforms, Listeria sp, Salmonella sp. and coagulase positive Staphylococcus aureus were evaluated by culture-dependent methods, as well as on the composition of the bacterial community, which was assessed by means of 454-pyrosequencing.

\section{Materials and Methods}

\subsection{Probiotic Cultures}

The probiotic preparation consisted of a mixture of Lactobacillus acidophilus (CUL-60), Lactobacillus acidophilus (CUL-21), Bifidobacterium bifidum (CUL-20), Bifidobacterium animalis subsp. lactis (CUL-34), Lactobacillus salivarius (CUL-61), Lactobacillus paracasei (CUL-08), Lactobacillus plantarum (CUL-66), Lactobacillus casei (CUL-06), Lactobacillus fermentum (CUL-67), Lactobacillus gasseri (CUL-09), Bifidobacterium animalis subsp. lactis (CUL-62), Bifidobacterium breve (CUL-74), Streptococcus salivarius subsp. thermophilus (CUL-68), Lactobacillus acidophilus (NCFM ${ }^{\mathrm{TM}}$ ), Bifidobacterium animalis subsp. lactis (HN019) and Lactobacillus rhamnosus (HN001) in equal proportions.

\subsection{Production of Raw Milk Cheeses, Ripening and Sampling}

Two groups of cheeses (probiotics and control) were made in three different seasons (winter, summer and autumn) in order to account for seasonal changes in cheese microbial communities. Cheese production was undertaken in artisanal scale in a local dairy manufacturer of a region known as "Serra da Mantiqueira", starting from 50L of raw cow's milk for each group. Both groups of cheeses were inoculated with a natural whey starter, obtained from the whey collected after cheese making in the previous day. The collected whey was stored in a sealed polypropylene container and left to ferment at room temperature overnight. 
Cheeses belonging to the probiotic group were inoculated with a sufficient amount of probiotic preparation to obtain a final concentration of $10^{6} \mathrm{CFU} / \mathrm{ml}$ of probiotic bacteria and $1 \%$ of natural whey starter, while the control group received only $1 \%$ of the natural starter. The milk in the vats belonging to each group was ripened for 30 minutes at $35-37^{\circ} \mathrm{C}$ after addition of whey starter and adjunct cultures, and then rennet (Ha- $\mathrm{La}^{\mathrm{TM}}-\mathrm{Christian}$ Hansen) was added according to the manufacturer's instructions. After 30 minutes, the curd was cut, stirred for 20 minutes, then heated to $48^{\circ} \mathrm{C}$ and stirred until the consistency was adequate for molding. Afterwards, the curds were transferred into $1 \mathrm{~kg}$ molds and pressed for 30 minutes on each side. Following, the cheeses were transferred to a brine $\left(20^{\circ}\right.$ Baumé) for 48 hours at $4{ }^{\circ} \mathrm{C}$, air dried, vacuum packed and then ripened at $10-15^{\circ} \mathrm{C}$. Samples were collected at day 1, 15, 30 and 45 of ripening and tested for the presence of total and thermotolerant coliforms, Salmonella sp., coagulase-positive Staphylococcus aureus, Listeria sp. and also stored for culture-independent analyses.

\subsection{Culture Dependent Analyses}

Microbiological analyses were carried out using FDA's Bacteriological Analytical Manual (BAM) preferred procedures. Total and thermotolerant coliform populations were estimated according to Kornacki \& Johnson (2001). Coagulase-positive Staphylococcus aureus populations were determined according to Bennet \& Lancette (2001). Salmonella sp. quantification was performed according to Wallace, Andrews, Jacobson, \& Hammack (2016). Listeria sp. populations were determined according to Hitchins (2016).

\subsection{Bacterial Community Identification: Total DNA Extraction and PCR Amplification}

Bacterial community in the cheese samples was identified to the genus level by means of 454 pyrosequencing of the 16S rRNA genes. All genera representing less than $0.01 \%$ of the total bacterial community were omitted from the results.

Total DNA of cheese samples was extracted using MoBio Powerfood Microbial DNA Isolation Kit (Mobio Laboratories), following manufacturer's instructions using $0.25 \mathrm{~g}$ of homogenized cheese samples. The resulting extracts were used as templates for PCR amplification and were stored at $-80{ }^{\circ} \mathrm{C}$ until used. The $16 \mathrm{~S}$ rRNA genes were amplified using primers 968F (5'-AACGCGAAGAACCTTAC-3') and 1378R (5'-CGGTGTGTACAAGGCCCGGGAACG-3'). For this, $5 \mu \mathrm{L}$ of total DNA extracted from the respective samples were added to microtubes containing $10 \mathrm{mM}$ dNTPs, $0,1 \mu \mathrm{M}$ of the respective primers, $500 \mathrm{mM} \mathrm{KCl}$,

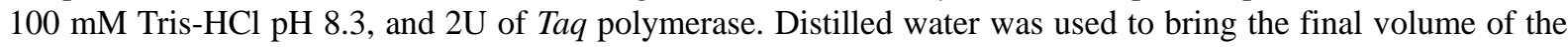
reaction to $50 \mu \mathrm{L}$. Amplification program consisted of an initial denaturation step at $95^{\circ} \mathrm{C}$ for $5 \mathrm{~min}$, followed by 35 cycles of denaturation for $30 \mathrm{~s}$ at $94^{\circ} \mathrm{C}$, annealing at $62^{\circ} \mathrm{C}$ for $30 \mathrm{~s}$, extension at $72^{\circ} \mathrm{C}$ for $40 \mathrm{~s}$, followed by a final elongation step at $72^{\circ} \mathrm{C}$ for $10 \mathrm{~min}$.

\subsection{Purification of Amplicons and Pyrosequencing}

Samples resulting from PCR amplification were purified using Illustra GFX PCR DNA and gel Band Purification Kit (GE Healthcare), followed by sequencing in Roche/454 (Roche Applied Science) using a GS-FLX Titanium sequencing kit. Sequence classification was carried out using MOTHUR software and RDP (Ribossomal Database Project - Michigan State) database.

\subsection{Statistical Analysis}

Results were analyzed by means of one-way ANOVA, followed by Tukey's post hoc test for paired comparisons with $95 \%$ confidence interval.

\section{Results and Discussion}

\subsection{Bacterial Communities of Raw Milk Cheeses with and Without the Addition of Probiotic Bacteria}

Raw milk cheeses inherently harbor a diverse microbial community, which accounts for their diversified sensory profiles. Compared to commercially available starters used in cheese making, indigenous lactic acid bacteria isolated from raw milk cheeses, bacteria found on surfaces of ripening racks and in traditional brines have been associated with higher scores for sensory characteristics. Also, the low presence of pathogens in most traditional ripened cheeses is attributed to the antimicrobial activities of several species of bacteria that form the autochthonous milk microbiota (Montel et al., 2014).

Results obtained through pyrosequencing (Table 1 and Figure 1) showed that microbial communities were very distinct in the three seasons. However, the genera Lactobacillus, Streptococcus and Lactococcus were the dominant taxa in all of them. Lactobacillus was a major constituent of the bacterial community of cheeses in the winter $(\approx 95-97 \%)$ and autumn $(\approx 70 \%)$, while in the summer, Streptococcus was the dominant genus $(\approx$ 51-54\%). Masoud et al. (2012) found similar results while evaluating Danish raw milk cheeses by means of 
pyrosequencing, however, in their study, Lactococcus was the predominant genus.

Table 1. Percentages of total sequence reads belonging to different bacterial genera in artisanal cheeses, produced in different seasons

\begin{tabular}{|c|c|c|c|c|c|c|c|}
\hline \multirow{2}{*}{ Family } & \multirow{2}{*}{ Genus } & \multicolumn{3}{|c|}{ Control } & \multicolumn{3}{|c|}{ Probiotic-enriched } \\
\hline & & Winter & Summer & Autumn & Winter & Summer & Autumn \\
\hline Bifidobacteriaceae & Bifidobacterium & $0.00 \%^{\mathrm{a}}$ & $0.00 \%{ }^{\mathrm{a}}$ & $0.00 \%{ }^{\mathrm{a}}$ & $0.1 \%^{\mathrm{a}}$ & $0.24 \%{ }^{\mathrm{a}}$ & $0.12 \%^{\mathrm{a}}$ \\
\hline \multirow{2}{*}{ Flavobacteriaceae } & Riemerella & $0.04 \%^{\mathrm{a}}$ & $0.03 \%^{\mathrm{a}}$ & $0.07 \%^{\mathrm{a}}$ & $0.1 \%^{\mathrm{a}}$ & $0.02 \%^{\mathrm{a}}$ & $0.08 \%^{\mathrm{a}}$ \\
\hline & Soonwooa & $0.21 \%^{\mathrm{a}}$ & $0.29 \%^{\mathrm{a}}$ & $0.50 \%{ }^{\mathrm{a}}$ & $0.2 \%^{\mathrm{a}}$ & $0.18 \%^{\mathrm{a}}$ & $0.62 \%^{\mathrm{a}}$ \\
\hline Staphylococcaceae & Staphylococcus & $0.11 \%^{\mathrm{a}}$ & $0.18 \%^{\mathrm{a}}$ & $0.01 \%^{\mathrm{a}}$ & $0.1 \%^{a}$ & $0.10 \%{ }^{a}$ & $0.01 \%^{\mathrm{a}}$ \\
\hline \multirow{3}{*}{ Carnobacteriaceae } & Isobaculum & $0.05 \%^{\mathrm{a}}$ & $0.19 \%^{\mathrm{a}}$ & $0.18 \%^{\mathrm{a}}$ & $0.1 \%^{\mathrm{a}}$ & $0.17 \%^{\mathrm{a}}$ & $0.25 \%{ }^{\mathrm{a}}$ \\
\hline & Jeotgalibaca & $0.12 \%^{\mathrm{a}}$ & $0.07 \%{ }^{\mathrm{a}}$ & $0.18 \%^{\mathrm{a}}$ & $0.1 \%^{\mathrm{a}}$ & $0.06 \%{ }^{\mathrm{a}}$ & $0.16 \%{ }^{\mathrm{a}}$ \\
\hline & Lacticigenium & $0.04 \%^{\mathrm{a}}$ & $0.14 \%^{\mathrm{a}}$ & $0.27 \%^{\mathrm{a}}$ & $0.0 \%^{\mathrm{a}}$ & $0.16 \%^{\mathrm{a}}$ & $0.22 \%^{\mathrm{a}}$ \\
\hline \multirow{5}{*}{ Enterococcaceae } & Bavariicoccus & $0.07 \%^{\mathrm{a}}$ & $0.56 \%{ }^{\mathrm{a}}$ & $0.09 \%^{\mathrm{a}}$ & $0.1 \%^{\mathrm{a}}$ & $0.42 \%^{a}$ & $0.10 \%^{\mathrm{a}}$ \\
\hline & Catellicoccus & $0.33 \%^{\mathrm{a}}$ & $4.28 \%^{\mathrm{a}}$ & $4.17 \%{ }^{\mathrm{a}}$ & $0.8 \%{ }^{\mathrm{a}}$ & $4.22 \%{ }^{\mathrm{a}}$ & $5.34 \%{ }^{\mathrm{a}}$ \\
\hline & Enterococcus & $0.02 \%^{\mathrm{a}}$ & $0.05 \%^{\mathrm{a}}$ & $0.06 \%^{\mathrm{a}}$ & $0.0 \%{ }^{\mathrm{a}}$ & $0.04 \%^{\mathrm{a}}$ & $0.02 \%^{\mathrm{a}}$ \\
\hline & Melissococcus & $0.01 \%^{\mathrm{a}}$ & $1.92 \%^{\mathrm{a}}$ & $0.20 \%^{\mathrm{a}}$ & $0.0 \%{ }^{\mathrm{a}}$ & $1.42 \%{ }^{\mathrm{a}}$ & $0.29 \%{ }^{\mathrm{a}}$ \\
\hline & Pilibacter & $0.01 \%{ }^{\mathrm{a}}$ & $3.99 \%{ }^{\mathrm{a}}$ & $0.12 \%^{\mathrm{a}}$ & $0.1 \%^{\mathrm{a}}$ & $3.75 \%{ }^{\mathrm{a}}$ & $0.16 \%^{\mathrm{a}}$ \\
\hline Lactobacillaceae & Lactobacillus & $97.39 \% \%^{a}$ & $24.07 \%{ }^{a}$ & $69.79 \%^{a}$ & $95.7 \%{ }^{b}$ & $32.07 \%{ }^{b}$ & $69.39 \%^{\mathrm{a}}$ \\
\hline \multirow{3}{*}{ Streptococcaceae } & Lactococcus & $0.13 \%^{\mathrm{a}}$ & $5.37 \%{ }^{a}$ & $8.87 \%^{a}$ & $0.2 \%^{\mathrm{a}}$ & $2.26 \% \%^{b}$ & $14.23 \%^{b}$ \\
\hline & Streptococcus & $0.11 \%^{\mathrm{a}}$ & $53.96 \% \%^{a}$ & $2.14 \%{ }^{a}$ & $1.0 \%{ }^{\mathrm{a}}$ & $51.02 \%{ }^{b}$ & $1.31 \%{ }^{b}$ \\
\hline & Lactovum & $0.01 \%^{\mathrm{a}}$ & $0.87 \%{ }^{\mathrm{a}}$ & $0.22 \%^{\mathrm{a}}$ & $0.0 \%{ }^{\mathrm{a}}$ & $1.02 \%{ }^{\mathrm{a}}$ & $0.25 \%^{\mathrm{a}}$ \\
\hline \multirow{9}{*}{ Enterobacteriaceae } & Citrobacter & $0.01 \%^{\mathrm{a}}$ & $0.03 \%^{\mathrm{a}}$ & $1.39 \%{ }^{a}$ & $0.0 \%^{\mathrm{a}}$ & $0.01 \%^{\mathrm{a}}$ & $0.61 \%{ }^{b}$ \\
\hline & Enterobacter & $0.01 \%^{\mathrm{a}}$ & $0.10 \%{ }^{a}$ & $4.93 \%{ }^{a}$ & $0.0 \%{ }^{\mathrm{a}}$ & $0.02 \%{ }^{b}$ & $3.20 \%{ }^{b}$ \\
\hline & Klebsiella & $0.00 \%^{\mathrm{a}}$ & $0.01 \%^{\mathrm{a}}$ & $2.44 \% \%^{a}$ & $0.0 \%{ }^{\mathrm{a}}$ & $0.01 \%{ }^{\mathrm{a}}$ & $0.69 \%{ }^{b}$ \\
\hline & Kluyvera & $0.01 \%^{\mathrm{a}}$ & $0.02 \%^{\mathrm{a}}$ & $0.66 \%^{\mathrm{a}}$ & $0.0 \%{ }^{\mathrm{a}}$ & $0.01 \%{ }^{\mathrm{a}}$ & $0.25 \%$ \\
\hline & Leclercia & $0.01 \%^{\mathrm{a}}$ & $0.14 \%^{a}$ & $1.55 \%^{a}$ & $0.0 \%{ }^{\mathrm{a}}$ & $0.05 \%{ }^{b}$ & $0.95 \%$ \\
\hline & Salmonella & $0.00 \%^{\mathrm{a}}$ & $0.00 \%^{\mathrm{a}}$ & $0.44 \%{ }^{a}$ & $0.0 \%{ }^{\mathrm{a}}$ & $0.00 \%^{\mathrm{a}}$ & $0.22 \%{ }^{b}$ \\
\hline & Morganella & $0.00 \%^{\mathrm{a}}$ & $0.01 \%^{\mathrm{a}}$ & $0.17 \%^{\mathrm{a}}$ & $0.0 \%{ }^{\mathrm{a}}$ & $0.01 \%^{\mathrm{a}}$ & $0.16 \%^{\mathrm{a}}$ \\
\hline & Obesumbacterium & $0.00 \%^{\mathrm{a}}$ & $0.11 \%^{\mathrm{a}}$ & $0.52 \%^{a}$ & $0.0 \%^{\mathrm{a}}$ & $0.06 \%{ }^{\mathrm{a}}$ & $0.34 \%{ }^{b}$ \\
\hline & Pluralibacter & $0.00 \%^{\mathrm{a}}$ & $0.00 \%^{\mathrm{a}}$ & $0.28 \%^{\mathrm{a}}$ & $0.0 \%^{\mathrm{a}}$ & $0.00 \%^{\mathrm{a}}$ & $0.23 \%^{\mathrm{a}}$ \\
\hline \multirow{2}{*}{ Moraxellaceae } & Acinetobacter & $0.78 \%^{\mathrm{a}}$ & $3.06 \%{ }^{\mathrm{a}}$ & $0.31 \%^{\mathrm{a}}$ & $0.7 \%^{\mathrm{a}}$ & $2.33 \%^{\mathrm{a}}$ & $0.12 \%^{\mathrm{a}}$ \\
\hline & Enhydrobacter & $0.51 \%^{\mathrm{a}}$ & $0.56 \%{ }^{\mathrm{a}}$ & $0.40 \%^{\mathrm{a}}$ & $0.6 \%^{\mathrm{a}}$ & $0.34 \%^{\mathrm{a}}$ & $0.62 \%^{\mathrm{a}}$ \\
\hline
\end{tabular}

Values of control and probiotic-enriched cheeses made in the same season with different superscripted letters are significantly different $(\mathrm{p}<0.05)$.

Considering that all cheeses were subjected to the same conditions during processing and ripening, the main factors that could have interfered in the composition of cheese bacterial communities in this study is the natural whey starter and the raw milk used for production. In this context, the bacterial community in the whey starter that is left to ferment overnight at room temperature could be influenced by the different temperatures in each season, as well as by the different species of bacteria introduced with the milk that was used in the production of the previous batch of cheeses. In the region that this study took place (Serra da Mantiqueira), which is situated at 1200 meters of altitude, the temperature usually ranges from $20-33^{\circ} \mathrm{C}$ in the summer and from $8-22$ in the winter and autumn.

Several species of bacteria are able to produce antimicrobial substances that act as biopreservatives. There are many types of antimicrobial compounds found in foods produced with raw milk, such as organic acids, bacteriocins, antifungals, diacetyl, hydrogen peroxide and others (O'Sullivan \& Cotter, 2017). These antimicrobial compounds, which are produced mainly by lactic acid bacteria, alter the intrinsic properties of fermented foods to the extent that they actually kill and inhibit the growth of spoilage and pathogenic microorganisms, rendering the product safer to consume and more shelf-stable. Perhaps the more complex of these substances are bacteriocins, which are antimicrobial peptides, produced by bacteria, which kill other competing bacteria in the environment (Deegan, Cotter, Hill, \& Ross, 2006).

On the other hand, the antimicrobial properties of bacteriocins and other antimicrobial compounds is not directed exclusively towards pathogenic or spoilage bacteria and can they also inhibit other beneficial or innocuous starter and non-starter lactic acid bacteria that may be sharing the environment and competing for the same 
resources. Corroborating this affirmation, Tymoszewska, Diep, Wirtek \& Alesandrzak-Piekaczyk (2017) demonstrated that Garvicin Q, a bacteriocin produced by Lactococcus garvieae, has a very broad spectrum of action, being capable of inhibiting Listeria monocytogenes and also several lactic acid bacteria species belonging to the genera Leuconostoc, Lactobacillus, Carnobacterium, Enterococcus and Pediococcus.

Our results showed that the incorporation of the multi-strain probiotic preparation exerted different effects on the predominant genera (Lactococcus, Streptococcus and Lactobacillus) in each season. In the winter, the addition of the preparation promoted a slight, but significant $(\mathrm{p}<0.05)$ reduction in Lactobacillus percentage, even though the preparation itself included 10 Lactobacillus species. This could indicate that some of the bacterial components of the preparation may have exerted inhibitory effects on autochthonous Lactobacillus species, which was not observed in the other seasons. On the other hand, in the summer, the percentage of Lactobacillus was higher in probiotic cheeses.

The effect of the preparation on the genus Lactococcus was also different in the three seasons. Probiotic-enriched cheeses presented lower Lactococcus sequence reads on summer $(\mathrm{p}<0.05)$ and a higher number of sequence reads $(\mathrm{p}<0.05)$ on autumn relative to the control group while in the winter, no effect was observed and Lactococcus was a minor member of the microbiota. Regarding the genus Streptococcus, we observed no significant effect in cheeses made in the winter and a significant $(\mathrm{p}<0.05)$ negative effect in both summer and autumn cheeses, regardless of the fact that Streptococcus thermophilus was present in the probiotic preparation. Members of the genus Bifidobacterium were absent in the control cheeses and apparently did not adapt well to cheese conditions, as the percentages for this genus were no higher than $0.25 \%$ in probiotic-enriched cheeses.

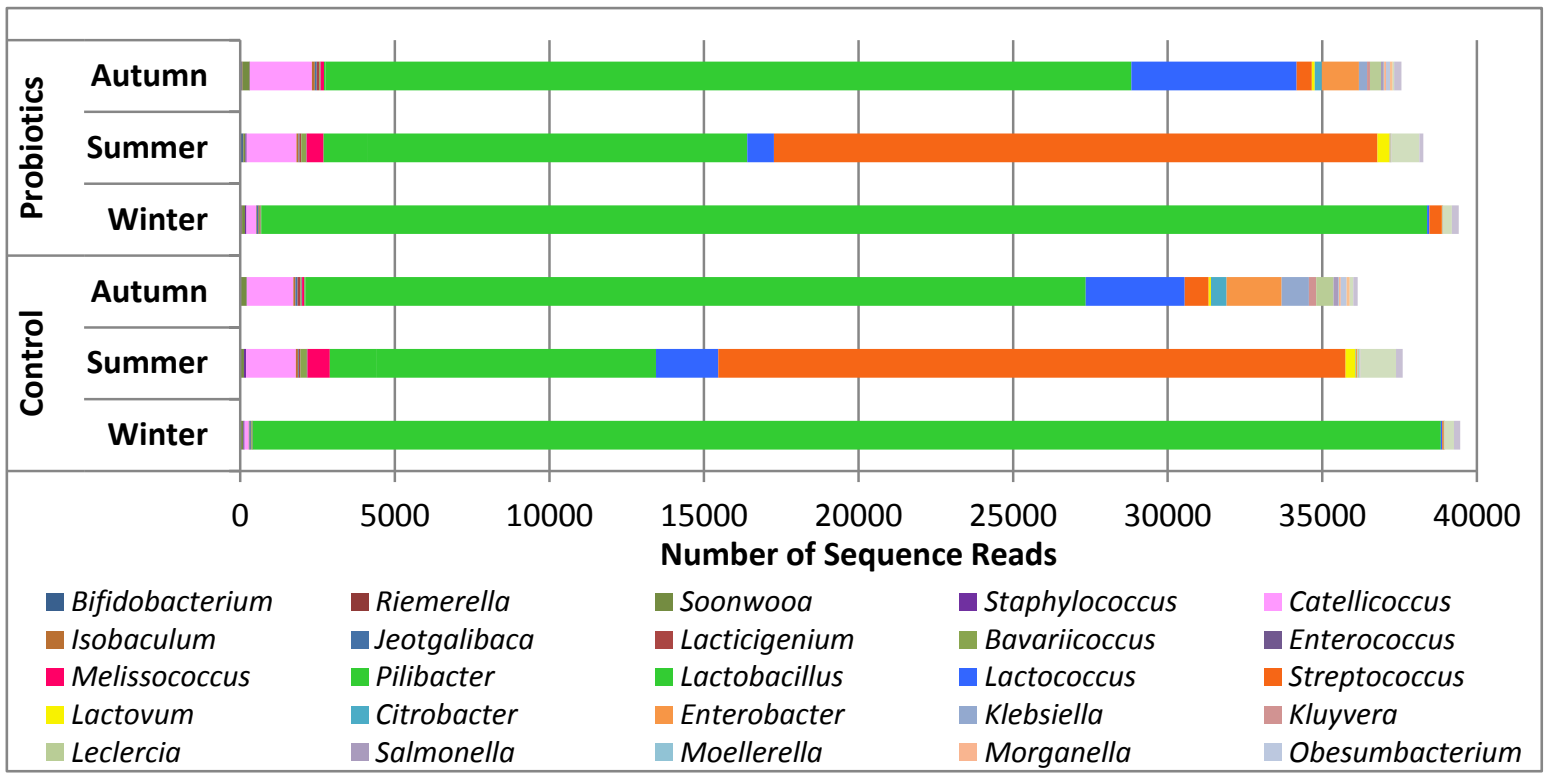

Figure 1. Main bacterial genera identified in the microbial community of traditional Brazilian semi-hard cheese

We observed that the cheeses produced in the winter had very low percentages of members of the Enterobacteriaceae family, relative to the percentages observed in summer and autumn. In Brazil this is a common observation because, in these months, the quality of water used in rural areas, which is often not treated, tends to worsen as well as the hygienic conditions, due to the abundance of rainfall. In summer and autumn, the probiotic-enriched cheeses presented significantly $(\mathrm{p}<0.05)$ lower percentages of Enterobacteriaceae when compared to the control group (Figure 2). In both mentioned seasons, total number of sequence reads of Enterobacteriaceae on probiotic group was approximately half of that observed in the control group, however, in the winter, the control and probiotic groups did not differ regarding Enterobacteriaceae concentrations. To establish a sense of proportion, it is important to point out that Enterobacteriaceae were present at greater quantities on autumn cheeses (up to 5,000 sequence reads), to a lesser extent on summer cheeses (up to 170 sequence reads) and much lesser in winter cheeses (up to 20 sequence reads). This seasonality can cause a great impact on raw milk cheeses quality because Enterobacteriaceae are known for causing off-flavors in raw milk cheeses. The fact that just adding probiotic cultures along with the starter reduced an average of $50 \%$ of Enterobacteriaceae sequence reads (Figure 2) on the seasons in which they were most prevalent may indicate 
that selected bioprotective cultures can be used as adjuncts on artisanal cheeses to mitigate or avoid off-flavors and defects such as early blowing, which is also caused by Enterobacteriaceae.

Westling et al. (2016) conducted a study on the contribution of this family to the sensory characteristics of soft raw milk cheeses and observed that the presence of Enterobacteriaceae could be predicted through the perception of taste and odor alone. Moderate correlation was found between the sensory characteristics identified as "manure", "ammonia", "pungent", "bitter" and "metallic" and high levels of Enterobacteriaceae cultivable at $37{ }^{\circ} \mathrm{C}$. In this context, reducing the occurrence of members of this family can be a positive consequence of employing bioprotective strains in artisanal cheeses, providing they do not alter their peculiar sensory characteristics or biogeographic identity of cheeses.
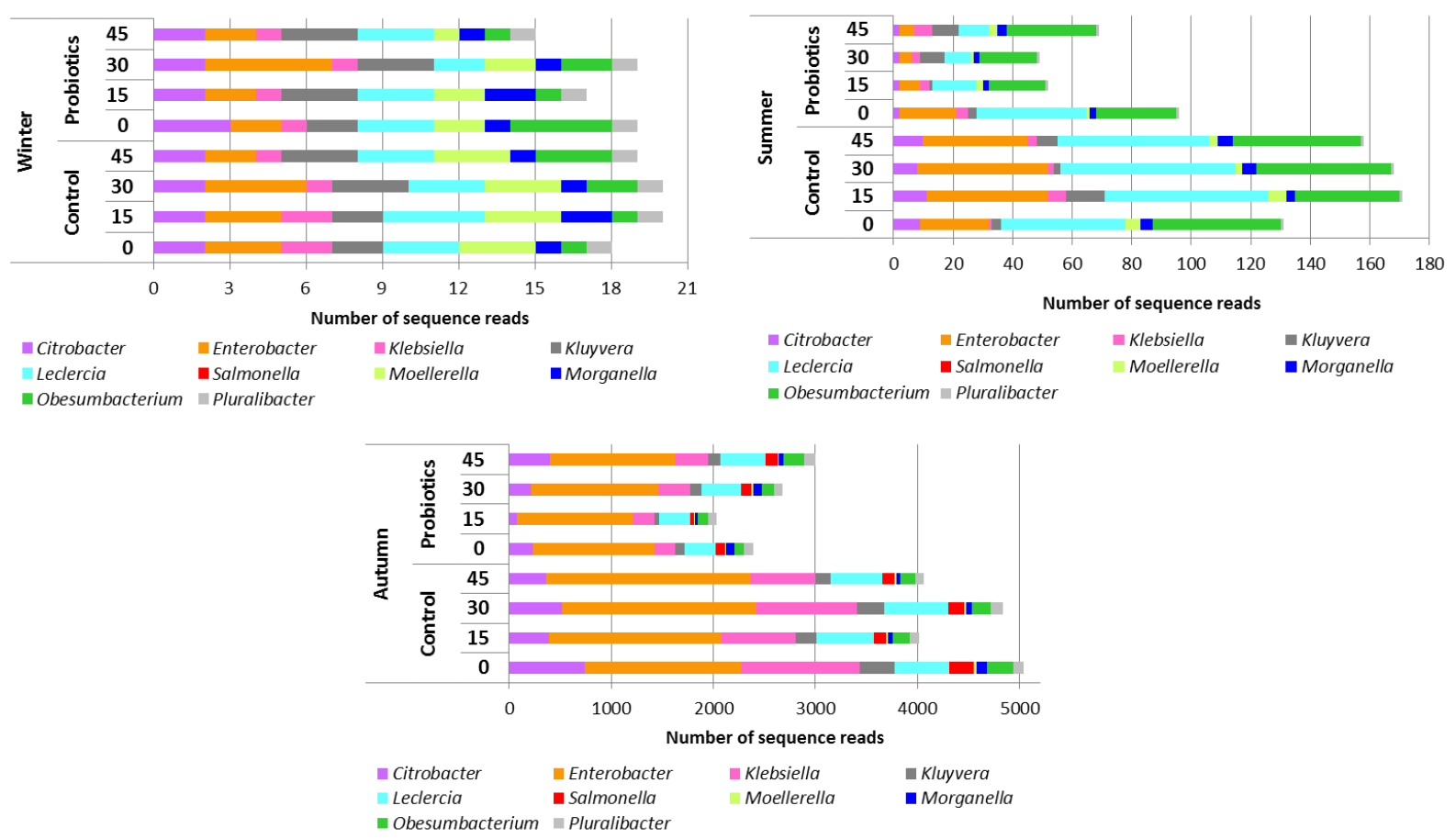

Figure 2. Comparison of sequence reads belonging to Enterobacteriaceae in Brazilian artisanal cheeses made with and without probiotics in different seasons

\subsection{Microbiological Safety Parameters of Brazilian "Queijo da Mantiqueira" with or without Added Probiotics}

With regards to parameters that indicate microbiological quality, it was observed that all but one set of cheese samples exceeded legal limits for thermotolerant coliforms (Table 2), which belonged to the control group. Samples from the first day after manufacturing belonging to this group had excessive numbers of thermotolerant coliforms, however, after 15 days of ripening this number decreased, fell below the limit accepted by Brazilian law and decreased even more with further ripening. It is important to remark that most of the raw milk cheese related laws require cheeses to be ripened for a minimum of 60 days to ensure safety, including the corresponding Brazilian law (Brasil, 2013). However, in this study both control and probiotic enriched cheeses met legal parameters since the 15th of ripening (probiotic-enriched cheeses since day 1), which points out that raw material quality and good processing practices are major factors that influence these indicators.

Despite presenting a lower number of sequence reads belonging to Enterobacteriaceae than cheeses made on autumn, cheeses produced in the summer presented higher counts of total and thermotolerant coliform per gram of product. This could indicate that the Enterobacteriaceae present in autumn cheeses were mostly inactive or in a non-cultivable state, a concept previously explored by authors like Alegría, Gonzáles, Diaz, \& Mayo (2011). In both cases, the number of sequence reads was approximately 50\% lower in the probiotic enriched cheeses, despite the fact that the same relation was not found in the culture-dependent method. 
Table 2. MPN (Most Probable Number) of total and thermotolerant coliforms in cheese manufactured in different seasons, subjected to different treatments

\begin{tabular}{llllllll}
\hline Group & Ripening (days) & \multicolumn{3}{c}{ Total coliforms (MPN/g) } & \multicolumn{3}{c}{ Thermotolerant coliforms (MPN/g) } \\
\hline & Winter & Summer & Autumn & Winter & Summer & Autumn \\
\hline Control & 1 & $<3,0$ & $>1.100$ & 14 & $<3,0$ & $>\mathbf{1 . 1 0 0}$ & $<3,0$ \\
& 15 & $<3,0$ & 1.100 & $<3,0$ & $<3,0$ & 240 & $<3,0$ \\
& 30 & $<3,0$ & 1.100 & 43,0 & $<3,0$ & 460 & 9,2 \\
& 45 & $<3,0$ & 43 & 23 & $<3,0$ & 43 & $<3,0$ \\
Probiotic-enriched & 1 & $<3,0$ & 460 & 1.100 & $<3,0$ & 460 & $<3,0$ \\
& 15 & $<3,0$ & $>1.100$ & 23 & $<3,0$ & 240 & $<3,0$ \\
& 30 & $<3,0$ & 1.100 & 460 & $<3,0$ & 210 & 3,6 \\
& 45 & $<3,0$ & 93 & 93 & $<3,0$ & 93 & $<3,0$ \\
\multicolumn{1}{l}{ Limits allowed by specific legislation } & Not specified & & Max. 1.000 MPN/g & \\
\hline
\end{tabular}

Numbers in bold: Exceeded legislation upper limit.

Staphylococcal Foodborne Disease (SFD) is one of the most common causes of diseases associated with food consumption and is a major public health concern. Although $S$. aureus can be completely eliminated from foods by heat treatment prior to consumption, staphylococcal enterotoxins produced during growth are resistant to heat, gastrointestinal proteases and can cause serious food poisoning. Symptoms include profuse vomiting, nausea, abdominal cramps and diarrhea (Kadariya, Smith, \& Thapaliva, 2014). Salmonella and Listeria can be found naturally in the environment and are the causative agents of several and severe foodborne disease outbreaks worldwide. Dairy can be a common source of infections caused by these bacteria because the animals which are the natural reservoirs of these microorganisms (fowl, sheep, goats, pigs) often share the same environment with milk producing animals (Heredia \& Garcia, 2018), especially in properties that adopt a free range farming system and produce cheeses in an artisanal manner. Brazilian law admits a limit of $1000 \mathrm{CFU} / \mathrm{g}$ of $S$. aureus in finished cheeses (Brasil, 2001), while Salmonella and Listeria must be absent in $25 \mathrm{~g}$ of finished product.

Overall contamination with coagulase positive Staphylococcus aureus was low and only was detected in five sets of cheese samples by culture-dependent method (Table 3), three of them belonging to the control group. Sequence reads belonging to Listeria sp. and Salmonella sp. were detected inconsistently by pyrosequencing, at very low numbers (lower than 250 sequence reads) and only in cheeses manufactured on autumn, but were not detected in any of the samples by culture-dependent methods.

Table 3. Results of viable counts of Coagulase + Staphylococcus aureus, Salmonella sp. and Listeria sp. in cheese manufactured in different seasons, subjected to different treatments

\begin{tabular}{llllllll}
\hline Group & Ripening (days) & \multicolumn{3}{l}{$\begin{array}{l}\text { Coagulase + Staphylococcus } \\
\text { aureus }(\text { CFU/g) }\end{array}$} & \multicolumn{2}{l}{$\begin{array}{l}\text { Salmonella } \text { sp. and Listeria sp. } \\
\text { (Presence in 25 g) }\end{array}$} \\
\hline \multirow{2}{*}{ Control } & 1 & Winter & Summer & Autumn & Winter & Summer & Autumn \\
\hline & 15 & 200 & 600 & - & - & - & - \\
& 30 & - & 700 & - & - & - & - \\
\multirow{4}{*}{ Probiotics } & 45 & - & - & - & - & - & - \\
& 1 & - & - & - & - & - & - \\
& 15 & 200 & 700 & - & - & - & - \\
& 30 & - & - & - & - & - & - \\
\multicolumn{1}{c}{ Limits allowed by Brazilian law } & 1000 CFU/g. & - & - & - & - \\
\hline
\end{tabular}

Although not negligible, the incidence of Listeria monocytogenes in Brazil is relatively low. Oxaran et al. (2018) studied the incidence of Listeria monocytogenes in cheese, milk and brines of five dairies and retail stores in two states of Brazil over the course of 7 months. The authors analyzed a total of 437 samples and found that only 4 samples were contaminated with this microorganism.

The factors that govern the incidence and survival of Listeria sp. in cheeses are well established. Some categories of cheese, mainly non-acidic, semisoft, soft and smear-ripened cheeses are the most susceptible to the growth of Listeria sp. There seems to be no evidence-based difference between pasteurized and raw milk cheeses 
when it comes to Listeria incidence because most of the contaminations are not linked to the quality of the raw milk, but to the lack of hygiene during post pasteurization or post processing steps (Gérard, El-Hajjaji, Nivonzima, Daube, \& Sindic, 2018). Like Listeria monocytogenes, Salmonella sp. is also more prone to be found at low acidity, high moisture cheeses that were manufactured under unsanitary conditions or were packed or stored improperly. Soft ripened cheeses like Camembert and red smear cheeses in general present a higher risk of Salmonella incidence than hard cheeses like parmesan and cheddar (Choi, Lee, Lee, Kim, \& Yoon 2016).

\section{Conclusions}

Our results showed that incorporating probiotic microorganisms in raw milk cheeses prior to processing can significantly reduce the numbers of Enterobacteriaceae since the beginning of ripening, improving overall quality. This can result in safer products and lead to less accumulation of fermentation end products produced by members of this family, thus reducing the occurrence of off-flavors. Overall microbial diversity was preserved in probiotic-enriched cheeses, indicating that no negative effect was exerted upon the potentially health promoting characteristics of the microbiota or the ability to generate positive sensory characteristics. Also, it was demonstrated that this type of cheese can be made in such a way that it is safe for consumption in a much shorter time than that which is established by Brazilian legislation.

The bacterial composition of "Queijo da Mantiqueira" varied significantly when produced in different seasons, however three genera of bacteria were always dominant, namely Lactobacillus, Streptococcus and Lactococcus. Major factors that seemed to interfere with this composition were the microbial composition of the raw milk used for the production of cheeses and the microbial composition of the natural whey starter, as well as the temperature in which the starter is left to ferment.

\section{Acknowledgements}

This study was partly funded by FAPESP and CAPES and was executed at the Biotechnology Department of Lorena School of Engineering, University of São Paulo, Lorena, SP, Brazil.

\section{References}

Alegría, Á., González, R., Díaz, M., \& Mayo, B. (2011). Assessment of microbial populations dynamics in a blue cheese by culturing and denaturing gradient gel electrophoresis. Current Microbiology, 62(2), 888-893. https://doi.org/10.1007/s00284-010-9799-7Homa Mahmoodzadeh

Bennet, R. W., \& Lancette, G. A. (2001). Staphyloccus aureus. In: Food and Drug Administration - FDA. BAM - Bacteriological Analytical Manual Online. 8th ed. Rev. A. Silver Spring. FDA. Chap.12.

Brasil. (2001). Resolução RDC no 12, de 2 de janeiro de 2001. Aprova o "Regulamento técnico sobre padrões microbiológicos em alimentos". Órgão emissor: ANVISA - Agência Nacional de Vigilância Sanitária. Retrieved from http://portal.anvisa.gov.br/

Brasil. (2013). Ministério da agricultura, pecuária e abastecimento gabinete do ministro. Instrução normativa $N^{o}$ 30, de 7 de agosto de 2013. Diário Oficial da União, Brasília, DF, 08 ago 2013. Seção 1, pp.19.

Casalta, E., Sorba, J., Aigle, M., \& Ogier, J. (2009). Diversity and dynamics of the microbial community during the manufacture of Calenzana, an artisanal Corsican cheese. International Journal of Food Microbiology, 133(3), 243-251. https://doi.org/10.1016/j.ijfoodmicro.2009.05.022

Chambers, D. H., Esteve, E., \& Retiveau, A. (2010). Effect of milk pasteurization on flavor properties of seven commercially available French cheese types. Journal of Sensory Studies, 25(4), 494-511. https://doi.org/10.1111/j.1745-459X.2010.00282.x

Choi, K., Lee, H., Lee, S., Kim, S., \& Yoon, Y. (2016). Cheese microbial risk assessments - A Review. Asian-Australasian Journal of Animal Sciences, 29(3), 307-314. https://doi.org/10.5713/ajas.15.0332

Deegan, L. H. Cotter, P. D., Hill, C., \& Ross, P. (2006). Bacteriocins: Biological tools for bio-preservation and shelf-life extension. International dairy Journal, 16(9), 1058-1071. https://doi.org/10.1016/j.idairyj.2005.10.026

Dutton, R. J., \& Wolfe, B. E. (2015). Fermented foods as experimentally tractable microbial ecosystems. Cell, 161(1), 49-55. https://doi.org/10.1016/j.cell.2015.02.034

Eid, R., El, J. J., Rashidy, A., Asfour, H., Omara, S., Kandil, M. M., Mahmood, Z., Hahne, J., \& Seida, A. A. (2016). Potential antimicrobial activities of probiotic Lactobacillus strains isolated from raw milk. Journal of Probiotics and Health, 4(2). https://doi.org/10.4172/2329-8901.1000138

Elkenany, M. R., Mona, M. E., Eltaysh, R. A., Zakaria, A. I., \& El-Baz, A. H. (2018). In vitro probiotic 
characteristics of Enterococcus species isolated from raw cow milk. International Journal of Probiotics \& Prebiotics, 13(2-3), 117-126.

Gérard, A., El-Hajjaji, S., Niyonzima, E., Daube, G., \& Sindic, M. (2018). Prevalence and survival of Listeria monocytogenes in various types of cheese - A review. International Journal of Dairy Technology, 71(4), 825-843. https://doi.org/10.1111/1471-0307.12552

Heredia, N., \& García, S. (2018). Animals as sources of food-borne pathogens: A review. Animal Nutrition, 4(3), 250-255. https://doi.org/10.1016/j.aninu.2018.04.006

Hitchins, A. D. (2016). Detection of Listeria monocytogenes in foods and environmental samples, and enumeration of Listeria monocytogenes in foods In: Food and Drug Administration, Bacteriological Analytical Manual Online. Chapter 10.

Hill, C., Guarner, F., Reid, G., Gibson, G. R., Merenstein, D. J., Pot, B., ... Sanders, M. E. (2014). The International Scientific Association for Probiotics and Prebiotics consensus statement on the scope and appropriate use of the term probiotic. Nature Reviews Gastroenterology \& Hepatology, 11(1), 506-514. https://doi.org/10.1038/nrgastro.2014.66

Kadariya, J., Smith, T. C., \& Thapaliya, D. (2014). Staphylococcus aureus and Staphylococcal Food-Borne disease: An ongoing challenge in public health. Biomed Research International, 1, 1-9. https://doi.org/10.1155/2014/827965

Kornacki, J. L., \& Johnson, J. L. (2001). Enterobacteriaceae, coliforms, and Escherichia coli as quality and safety indicators. In: F. P. Downes, \& K. Ito (4th ed.), Compendium of methods for the microbiological examination of foods (pp. 69-82). Washington, DC: American Public Health Association (APHA). https://doi.org/10.2105/9780875531755ch08

Law, B., \& Tamime, A. Y. (2010). Technology of cheesemaking. 2nd Ed. United Kingdom: Wiley-Blackwell. pp. 482. https://doi.org/10.1002/9781444323740

Masoud, W., Vogensen, F. K., Lillevang, S., Al-Soud, W. A., Sorensen, S. J., \& Jakobsen, M. (2012). The fate of indigenous microbiota, starter cultures, Escherichia coli, Listeria innocua and Staphylococcus aureus in Danish raw milk and cheeses determined by pyrosequencing and quantitative real time (qRT)-PCR. International Journal of Food Microbiology, 153(1-2), 192-202. https://doi.org/10.1016/j.ijfoodmicro.2011.11.014.

Montel, M., Buchin, S., Mallet, A., Delbes-Paus, C., Vuitton, D. A., Desmasures, N., \& Berthier, F. (2014). Traditional cheeses: Rich and diverse microbiota with associated benefits. International Journal of Food Microbiology, 177(1), 136-154. https//doi.org/10.1016/j.ijfoodmicro.2014.02.019

O’Sullivan, O., Cotter, P. D. (2017). Microbiota of raw milk and raw milk cheeses. In: P. McSweeney, P. Fox, P. Cotter \& D. Everett (4th ed.), Cheese: Chemistry, physics and microbiology. Academic press. Elsevier. https://doi.org/10.1016/B978-0-12-417012-4.00012-0

Oxaran, V., Lee, S. H. I., Chaul, L. T., Corassin, C. H., Barancelli, G. V., Alves, V. F., ... De Martinis, E. C. P. (2017). Listeria monocytogenes incidence changes and diversity in some Brazilian dairy industries and retail products. Food Microbiology, 68(1), 16-23. https://doi.org/ 10.1016/j.fm.2017.06.012.

Quigley, L., O’sullivan, O., Stanton, C., Beresford, T. P., Ross, R. P., Fitzgerald, G. F., \& Cotter, P. D. (2013). The complex microbiota of raw milk. FEMS Microbiology Reviews, 37(5), 664-698. https://doi.org/10.1111/1574-6976.12030.

Tymoszewska, A., Diep, D. B., Wirtek, P., \& Aleksandrzak-Piekarczyk, T. (2017). The non-lantibiotic bacteriocin Garvicin Q targets Man-PTS in a broad spectrum of sensitive bacterial genera. Scientific Reports, 7, 1-14. https://doi.org/10.1038/s41598-017-09102-7

Valente, G. L. C., Acurcio, L. B., Freitas, L. P. V., Nicoli, J. R., Silva, A. M., Souza, M. R., \& Penna, C. F. A. M. (2019). In vitro and in vivo probiotic potential of Lactobacillus plantarum B7 and Lactobacillus rhamnosus D1 isolated from Minas artisanal cheese. Journal of Dairy Science, 107(7), 5957-5961. https://doi.org/10.3168/jds.2018-15938

Wallace, H., Andrews, W. H., Jacobson, A., \& Hammack, T. (2016). Salmonella. In: Food and Drug Administration, Bacteriological Analytical Manual Online. Chapter 5.

Westling, M., Tham, M., Jass, J., Nilsen, A., Öström, Å., \& Tham, W. (2016). Contribution of Enterobacteriaceae to sensory characteristics in soft cheeses made from raw milk. Procedia Food Science, 
7(1), 17-20. https://doi.org/10.1016/j.profoo.2016.02.075

Yoon, Y., Lee, S., \& Choi, K. (2016). Microbial benefits and risks of raw milk cheese. Food Control, 63(1), 201-215. https://doi.org/10.1016/j.foodcont.2015.11.013

\section{Copyrights}

Copyright for this article is retained by the author(s), with first publication rights granted to the journal.

This is an open-access article distributed under the terms and conditions of the Creative Commons Attribution license (http://creativecommons.org/licenses/by/4.0/). 